Голобородько М. Ю., к.т.н., с.н.с.;

Кірпічніков Ю. А., к.т.н.;

Головченко О. В.;

Добронравін Ю. В.

Центр воєнно-стратегічних досліджень Національного університету оборони України імені Івана Черняховського, Київ

\title{
Питання забезпечення сумісної обробки інформації від різнорідних засобів спостереження та розвідки в АСУ військового призначення
}

Резюме. У статті на основі аналізу концептуальних підходів щодо забезпечення інтероперабельності автоматизованих систем управління військового призначення розглянуто систему інформаційних вимог до інтеграційної складової різних технічних засобів спостереження та розвідки, що дасть змогу підвищити точність і достовірність сумісної обробки розвідувальної інформації.

Ключові слова: інтероперабельність; технічні засоби спостереження та розвідки; інтеграційна складова; обробка розвідувальної інформації.

Постановка проблеми. Аналіз ведення локальних війн і збройних конфліктів кінця XX - начала XXI століть свідчить про те, що бойові дії стали дуже динамічними, a застосування високоточної зброї дозволяє досягнути мети в найкоротший строк. У зазначених умовах боротьба за виграш часу 3 планування i завдання вогневого ураження противнику (ВУП) носить для обох воюючих сторін винятково гострий характер. Успіх буде належати тому, хто зуміє за найкоротший час зібрати і обробити необхідну інформацію, прийняти рішення, поставити завдання i організувати дії військ, підготувати і завдати удари по визначених цілях, вчасно підтягнути i ввести резерви. Між іншим обсяги інформації, яку потрібно зібрати, обробити i передати, безупинно збільшуються. I зазначена тенденція зберігатиметься у подальшому.

3 метою підвищення оперативності i якості управління військами та силами у багатьох країнах світу, ведуться роботи, пов'язані 3 впровадженням у процеси управління інформаційні системи (автоматизовані системи управління). Одним 3 основних достоїнств їх використання - це автоматизація процесів інформаційного забезпечення, тобто автоматизація процесів збору, обліку, класифікації та систематизації даних, аналізу i розподілу підготовленої інформації. У зв'язку 3 цим питання забезпечення сумісної обробки інформації від різнорідних засобів спостереження та розвідки в автоматизованих системах управління військового призначення набувають особливої актуальності.

Ступінь розробленості проблеми. Відповідно до другого розділу Стратегічного оборонного бюлетеня [1], одним із завдань, що покладено на ЗС України, $\epsilon$ створення автоматизованої системи C4ISR (Command, Control, Communications, Computers, Intelligence, Surveillance and Reconnaissance) складових сил оборони, яка відповідає стандартам, доктринам і рекомендаціям НАТО на всіх рівнях управління (тактичному, оперативному та стратегічному) із визначеною специфікою базових можливостей.

У НАТО використовують архітектурні підходи до впровадження інформаційних систем. Поняття "C4ISR" визначається як архітектура та конщепція взаємодії складових системи бойового управління оперативного та оперативно-стратегічного рівня [2,3]. Серед них оперативно-стратегічна розвідка, спостереження та військова розвідка (Intelligence, Surveillance and Reconnaissance) is системами управління, контролю, зв'язку та обчислювальними засобами (Command, Control, Communication, Computers) в єдиному інформаційному середовищі, яке, у свою чергу, забезпечує інтеграцію навігаційної, загальногеографічної та тактичної інформації в єдиній географічній системі координат. Спроможності, що закладені в архітектуру та концепцію C4ISR, дають змогу:

автоматично визначати положення i переміщення своїх підрозділів та військ противника (автоматично відображається на електронних картах); 
обирати маршрути руху; видавати цілевказування засобам вогневого ураження;

інформувати свої підрозділи про дії і місцезнаходження їх сусідів і противника.

Для вирішення цих завдань найбільш актуальною $\epsilon$ задача інтеграції технічних засобів спостереження та розвідки для сумісної обробки розвідувальної інформації [4], що потребує виконання великого переліку вимог щодо, так званої, інтероперабельності систем. До числа основних слід віднести такі вимоги: інформаційні, системні, динамічні, енергетичні та конструкторсько-технологічні. $\mathrm{У}$ роботі розглянуто систему інформаційних вимог, яка повинна враховувати такі концепції: інформатизації, індивідуалізації, інтеграції та інтелектуалізації.

Метою статті $є$ визначення інформаційних вимог до інтеграційної складової різних технічних засобів спостереження та розвідки на основі аналізу концептуальних підходів забезпечення інтероперабельності автоматизованих систем управління військового призначення.

\begin{tabular}{lcr}
\multicolumn{1}{c}{ Виклад } & основного & матеріалу. \\
Концепиія & інформатизациї & повинна
\end{tabular}
грунтуватися на забезпеченні високого ступеня достовірності та повноти результатів розвідки, які визначаються високою ймовірністю розпізнавання типу цілі (об'єкта), його тактичного призначення. Концепція інформатизації вимагає, щоб розвідувальна інформація була вагомою, інформативною, достовірною, своєчасною і достатньою для прийняття рішення на вогневе ураження противника (ВУП).

Конщепџія індивідуалізащії заснована на тому, що розвідувальна інформація повинна бути орієнтована на конкретного споживача: оператора підсистеми збору, аналізу, обробки та видачі інформації, керівників (особовий склад) груп планування ВУП, начальників штабів різного рівня, командирів тощо $\mathrm{i}$ розрахована на певний рівень прийняття рішення. Алгоритми обробки інформації відповідно до цієї концепції повинні бути гнучкими i не тільки обробляти, але i представляти інформацію від низу до верху у зручній для користувача формі. Ступінь узагальнення інформації має збільшуватися із зростанням оперативного рівня, при цьому не повинно допускатися перевантаження каналів зв'язку і обчислювальних потужностей (засобів) вищого рівня (штабу) надлишкової інформацією і втрати важливої інформації, необхідної для прийняття рішення на цьому рівні.
Кониепиія інтеграйї має передбачати інформаційне об'єднання всіх видів розвідки (радіолокаційної і радіотехнічної, звукової, оптичної), комплексування засобів розвідки різних діапазонів, об'єднання всіх засобів обробки розвідувальних відомостей за характером подання інформації, розподіл обчислювального ресурсу відповідно до характеру розвідувальних завдань, створення просторово агрегованих комплексів і локальних мереж.

Концепиія інтелектуалізації пов'язана 3 теорією штучного інтелекту і заснована на математичній логіці, структурної лінгвістики, теорії інформаційних структур і теорії евристичного пошуку.

Сутність проблеми щодо побудови інтеграційної складової автоматизованої системи управління та вироблення рекомендацій (вимог) з обробки розвідувальної інформації, що поступає від різнорідних за фізичним принципом дії, точністю та достовірністю інформації джерел знаходиться у протиріччі між вимогами про необхідність скорочення часу на здійснення вогневого впливу на ціль (ураження цілі) і вимогами до підвищення точності визначення іiі координат та розмірів, достовірності (певності) та повноти iii характеристик.

Вирішенням протиріччя $є$ вибір критерію оптимальності, що дає змогу судити про кращій варіант. За критерій оптимальності $U$ беруть максимум показника ефективності вогневого ураження цілі (об'єкта) $M^{*}$, що характеризує шкоду (ступінь ураження), нанесену противнику:

$$
U=\max \left\{M^{*}{ }_{j}\right\}
$$

де $M^{*}{ }_{j}$ - значення показника ефективності стрільби по цілі, розрахованого при заданій $j$-й точності визначення координат з урахуванням своєчасності виявлення (ураження) цілі.

Вимоги (рекомендаціi), що розробляються для засобів/сенсорів (підрозділів) розвідки, мають відповідати характеру (класу) цілей (об’єктів), що розглядаються. У цьому випадку ступінь ураження $M^{*}$ необхідно визначити 3 урахуванням своєчасності виявлення цілі (об'єкта) і розрахувати за формулою:

$$
M^{*}=M \times P c .8,
$$

де $M$ - математичне сподівання відносного числа уражених окремих цілей зі складу групової (ступінь ураження об'єкта);

Pс.в - імовірність своєчасного виявлення цілі (об'єкта). 
У випадку, коли рекомендації розробляються для органів управління, які приймають рішення на підготовку вогню по конкретних вже розвіданих цілях, ступінь ураження $M^{*}$ необхідно розраховувати 3 урахуванням своєчасності (оперативності) iіi ураження засобами, що залучаються, за формулою:

$$
M^{*}=M \times P c,
$$

де $P c$ - імовірність своєчасного вогню артилерії по розвіданій цілі.

Якщо ціль, що розглядається,
відноситься до класу окремих високоманеврених цілей, то у формулах (2) i (3) замість $M$ слід узяти імовірність ураження цілі $P$ і розраховувати $P^{*}$ замість $M^{*}$.

Незалежно від призначення вимог (пропозицій, рекомендацій), що розробляються, проблема обробки розвідувальної інформації тісно пов'язана 3 проблемою вибору математичного забезпечення для автоматизованої системи обробки розвідувальних даних. Для практичних розрахунків $M^{*}$ або $P^{*}$ необхідно розробити методики визначення ступеня ураження об'єкта ( $M$ або $P$ ), а також імовірність своєчасного (оперативного) виявлення (ураження) об’єкта (цілі) [5].

Для підвищення надійності ураження цілей необхідно також ураховувати ймовірність достовірності даних про ціль $Р \partial$. Урахування ii здійснюється перемноженням $M^{*}$ на $P \partial$.

Але на сьогодні методика визначення $P \partial$ належним чином не розроблена. У якості наближеної оцінки можна скористатися залежністю:

$$
P \partial=\frac{n}{m},
$$

де $m$ - число розвідувальних ознак цілі;

$n$ - кількість розвідувальних ознак, що використовуються усіма засобами розвідки, від яких надійшли дані про ціль.

Помилковий (недостовірний) результат може бути отриманий як 3 технічних причин (недосконалість даної конструкції засобу), у результаті помилок оператора, що працює 3 даним засобом, так і в результаті заходів, проведених противником.

На практиці при проведені тих або інших вимірів і обчислень, особливо у тих випадках, коли помилковий результат може призвести до невиконання відповідальної бойової задачі, часто застосовують дублювання вимірів (обчислень). Виміри (виявлення) проводять однотипними або різнотипними засобами незалежно одне від одного.

Принцип дублювання вимірів різко підвищує достовірність результату розвідки. Нехай $P_{1}$ і $P_{2}$ - імовірності того, що достовірний результат видали відповідно перший і другий засоби, а $q_{1}$ i $q_{2}$ - імовірності отримання недостовірного результату першим і другим засобами. Використовуючи теорему про додавання i множення ймовірностей, визначимо імовірність події, яка подається у вигляді суми декількох несумісних подій, кожна $з$ яких є добутком декількох подій. Тоді ймовірність того, що один або обидва засоби видали недостовірний результат, тобто ймовірність незадовільного кінцевого результату, визначиться за виразом:

$$
q_{n . \partial .}=q_{1} P_{2}+q_{2} P_{1}+q_{1} q_{2} .
$$

Якщо прийняти $P_{1}=P_{2}=0,9$, а $q_{1}=q_{2}=$ 0,1, то $q_{n . \text {.. }}=0,19$.

Таким чином, при використанні принципу дублювання істотно зменшується ймовірність отримання грубих помилок, але при цьому зростає ймовірність того, що вогнева задача своєчасно не буде виконана. Для істотного підвищення достовірності результатів розвідки при одночасному виконанні вимог до своєчасності визначення координат цілі $є$ два шляхи:

а) створення високонадійних засобів розвідки як за рахунок більш досконалих конструктивних рішень, так i за рахунок раціонального ступеня автоматизації засобів розвідки;

б) застосування трьох засобів для визначення координат цілі, тоді ймовірність отримання недостовірного результату, або, що теж саме, ймовірність відкриття вогню при виконанні даного засобу розвідки $q_{n . \partial .}=q_{1} q_{2} q_{3}$.

Імовірність того, що у крайньому випадку два засоби визначать координати цілі вірно, визначається із сукупності таких подій:

усі три засоби дали достовірний результат;

перший і другий засіб дали достовірний, а третій - недостовірний;

перший і третій засоби дали достовірні результати, а другий - недостовірний;

другий і третій засоби дали достовірні результати, а перший - недостовірний.

Тоді ймовірність того, що ціль достовірна і стрільба буде можлива після першого циклу виявлення цілі:

$$
P_{\partial}=P_{1} P_{2} P_{3}+P_{1} P_{2} q_{3}+P_{1} q_{2} P_{3}+q_{1} P_{2} P_{3}
$$


Якщо прийняти $P_{1}=P_{2}=P_{3}=0,9 ;$ а $q_{1}=$ $q_{2}=q_{3}=0,1$, то $P_{\partial}=0,972$, таким чином забезпечується i достовірність визначення координат цілі та своєчасність відкриття вогню за умови, що виявлення кожним засобом теж своєчасна, а вимір усіма засобами здійснювався одночасно.

Таким чином, ведення розвідки одного об'єкта трьома засобами одночасно практично гарантує достовірність визначення його координат.

Висновки. У роботі розглянуто принципи оброблення комплексної розвідувальної інформації від різнорідних джерел систем розвідки.

Завдання інтеграції засобів розвідки i сумісної обробки розвідувальної інформації має полягати у забезпеченні безперервного циклу автоматизованої (автоматичної) обробки інформації від входу сенсору (просторово-часова обробка первинних параметрів) до іiі детальної інтегрованої обробки (оперативно-інформаційна обробка).

Наявність великої кількості технічних засобів розвідки передбачає їх комплексне застосування i, відповідно, комплексну обробку розвідувальних даних (відомостей).

Комплексна обробка розвідувальних даних (відомостей) сприяє підвищенню достовірності та точності визначення координат цілі. Засоби розвідки мають різну точність визначення координат цілі, тому отримані координати будуть характеризуватися неоднаковими серединними помилками їх визначення.

\section{СПИСОК ВИКОРИСТАНОЇ ЛІТЕРАТУРИ}

1. Про рішення Ради національної безпеки і оборони України від 20 травня 2016 року “Про Стратегічний оборонний бюлетень України” [Електронний ресурс]: указ [видано Президентом України 06 червня 2016 р. № 240/2016]. - - Режим доступу: http://www.president.gov.ua/documents/2402016-20137.

2. C4ISR Architecture Framework Version 2.0 [Electronic Resource] // C4ISR Architecture Working Group U.S. Department of Defense. - 1997. - Mode of access: http://www.afcea.org/education/courses/archfwk2.pdf.

3. Szlachta B. NATO Architecture Framework. NATO Operational View. [Electronic Resource] / Bernard Szlachta // Noble Prog. - 2016. - Mode of access: http://training-coursematerial.com/index.php?title=Nato_ Architecture_Framework_(NAF)_-_3.3_-_NATO_ Operational_V ew\&printable $=$ yes.

4. Стужук П. I. Теоретичні основи i практичні рекомендації щодо обробки розвідувальних відомостей (даних) / П. І. Стужук // К: НАОУ, 1998. $82 \mathrm{c}$.

5. Ю. Ф. Кучеренко / Методика загальної оцінки ефективності автоматизованої системи управління міжвидового угруповання військ// Харьков: Наука і техніка Повітряних Сил Збройних Сил України, 2013, № 4 (13).

Стаття надійшла до редакції 11.04.2018

Голобородько М. Ю., к.т.н., с.н.с.;

Кирпичников Ю. А., к.Т.н.;

Головченко А. В.;

Добронравин Ю. В.

Центр военно-стратегических исследований Национального университета обороны Украины имени Ивана Черняховского, Киев

Вопросы обеспечения совместной обработки информации от разнородных средств наблюдения и разведки в АСУ военного назначения

Резюме. В статье на основе анализа концептуальных подходов обеспечения интероперабельности автоматизированных систем управления военного назначения рассмотрена система информационных требований к интеграционной составляющей различных технических средств наблюдения и разведки, что позволит повысить точность и достоверность совместной обработки разведывательной информации.

Ключевые слова: интероперабельность; технические средства наблюдения и разведки; интеграционная составляющая; обработка разведывательной информации.

M. Goloborodko, PhD (Technical), senior researcher;

Y. Kirpichnikov, PhD (Technical);

O. Golovchenko;

Y. Dobronravin

Military Strategic Research Center of the National Defence University of Ukraine named after Ivan Cherniakhovskyi, Kyiv

The issues of ensuring the joint processing of information from various means of surveillance and reconnaissance to the military automated control system

Resume. In the article, based on the analysis of conceptual approaches to ensuring the interoperability of automated military command systems, the system of information requirements for the integration component of various technical means of surveillance and intelligence is considered, which will increase the accuracy and reliability of joint processing of intelligence information.

Keywords: interoperability; technical means of surveillance and intelligence; integration component; processing of intelligence information. 